\title{
Development of PCR method for fast detection of Ophiostoma floccosum in wood chips
}

\author{
Yeo Hong Yun, Dong Yeon Suh, Seung Yeol Son and Seong Hwan Kim*
}

Department of Microbiology and Institute of Basic Sciences, Dankook University, Cheonan 330-714, Korea.

Accepted 26 April, 2013

\begin{abstract}
Ophiostoma floccosum is one of blue stain fungi that cause cosmetic damage in softwood. To develop a molecular maker for the detection of 0 . floccosum, we designed Oflo1 and Oflo2 primers based on the $\beta$-tubulin gene. PCR assay with eleven isolates of $O$. floccosum and nine other blue stain and discoloring fungal species (moulds) proved that the designed primers specifically amplified a $333 \mathrm{bp}$ sized DNA band only from genomic DNA of $O$. floccosum isolates. Together with microwave heating extraction of spore DNA, we could detect $O$. floccosum within $2 \mathrm{~h}$ on artificially inoculated wood chip. We believed that the developed PCR method will be useful where detection of target species such as $O$. floccosum is required.
\end{abstract}

Key words: Ophiostoma floccosum, Species-specific primer, $\beta$-tubulin gene.

\section{INTRODUCTION}

Ophiostoma is a genus of fungi within the Ascomycota. This genus contains numerous species some of which are associated with bark beetles. Several Ophiostoma species are known as plant pathogens (for example, Ophiostoma ulmi, O. novo-ulmi), while many can cause blue stain on living trees, logs and freshly cut or dried and rewetted wood (for example, $O$. piceae, $O$. floccosum, $O$. piliferum, $O$ setosum). Blue stain, a cosmetic defect in wood that results in significant economical loss to forest products industries, is caused by growth of melanized hyphae or sporing structures inside or on the wood. The Ophiostoma piceae complex includes nine species based on morphology, culture characteristics, mating compatibility and sequence of internal transcribed spacer regions of the rDNA (de Beer et al., 2003). In the complex, $O$. piceae, $O$. canum, $O$. floccosum and $O$. setosum have been reported as coniferous group (Harrington et al.,
2001), while O. quercus, O. catonianum, and the Dutch elm disease fungi: $O$. ulmi, $O$. novo-ulmi, and $O$. himalulmi as hardwood group. They are known to be a polyphyletic group of morphologically similar fungi. For this reason, delineation and identification of Ophiostoma species requires fine mycology skills and modern techniques.

Molecular approach has been used for the differentiation of Ophiostoma species by PCR and Restriction Fragment Length Polymorphism (RFLP) analysis of the 18S rRNA gene (Kim et al., 1999a), the species-specific detection of $O$. piceae and $O$. quercus by PCR using the internal transcribed spacer (ITS) DNA sequence-derived primers (Kim et al., 1999b), and the differentiation of $O$. piliferum from other blue stain Ophiostoma species by PCR and RFLP (Schroeder et al., 2001). 
Table 1. Blue stain fungal isolates and other fungal species used in this study.

\begin{tabular}{|c|c|c|c|}
\hline Species & Isolate no. $^{a}$ & Host & Origin/source \\
\hline \multirow{10}{*}{ Ophiostoma floccosum } & DUCC0514 & Japanese black pine & Korea \\
\hline & DS1/3B-2 & Unknown & Canada/AU \\
\hline & KUC2032 & Radiata pine & New Zealand \\
\hline & KUC2319 & Japanese red pine & Korea \\
\hline & KUC2114 & Nut pine & Korea \\
\hline & KUC2420 & Nut pine & Korea \\
\hline & KUC2759 & Radiata pine & New Zealand \\
\hline & KUC2417 & Japanese red pine & Korea \\
\hline & KUC2415 & Japanese red pine & Korea \\
\hline & KUC2419 & Japanese red pine & Korea \\
\hline O. setosum & AU160-25 & Unknown & Canada \\
\hline O. minus & AU123-151 & Jack pine & Canada \\
\hline Leptographium terebrantis & CBS118620 & Japanese black pine & United states \\
\hline Penicillium sp. & DUCC408 & Japanese black pine & Korea \\
\hline Trichoderma sp. & DUCC409 & Japanese red pine & Korea \\
\hline
\end{tabular}

${ }^{a}$ DUCC, Dankook University Culture Collection, Korea; CBS-KNAW, Centraalbureau voor Schimmelcultures - an Institute of the Royal Netherlands Academy of Arts and Sciences (KNAW), The Netherlands; KUC, Korea University Culture Collection, Korea; AU, Dr. Adnan Uzunovic's personal collection, FP Innovations - Forintek Division, Canada. JW, Dr. Joan Weber, Centre for Forestry and Climate Change, Forest Commission, UK.

Currently, there has been no known molecular marker for $O$. floccosum, one of common blue stain species reported worldwide including Korea (Yun et al., 2009). In this study, we report a PCR-based molecular marker for differentiating $O$. floccosum from other blue stain fungi. The specificity of the developed molecular maker was demonstrated through specificity test on DNA samples and fungal samples on wood chips.

\section{MATERIALS AND METHODS}

Cultures of the Ophiostoma species and other fungi used for this study are shown in Table 1. The identification of all the obtained fungal isolates was verified before being used for the present study based on morphological characters and molecular data based on the nucleotides sequence of the $\beta$-tubulin gene. They were maintained in a deep freezer at $-70^{\circ} \mathrm{C}$ until used. For genomic DNA extraction, all the fungi were grown on cellophane-layered $2 \%$ malt extract or potato dextrose agar for 5 days at 20 or $25^{\circ} \mathrm{C}$. Mycelial harvest, DNA extraction using the drilling method, and PCR were performed as described by Kim et al. (1999b). For the design of species-specific primers, the $\beta$-tubulin gene was amplified by PCR with primers T10 (O'Donnell and Cigelnik, 1997) and BT12 (Schroeder et al., 2001) using Techne TC 3000 Thermal Cycler. Amplification of the $\beta$ tubulin gene was performed as follows: $95^{\circ} \mathrm{C}$ for $3 \mathrm{~min}$, followed by 30 cycles consisting of $95^{\circ} \mathrm{C}$ for $30 \mathrm{~s}, 56^{\circ} \mathrm{C}$ for $30 \mathrm{sec}$ and $72^{\circ} \mathrm{C}$ for $30 \mathrm{~s}$, and one final cycle of extension at $72^{\circ} \mathrm{C}$ for $5 \mathrm{~min}$. Taq DNA polymerase was purchased from Roche Diagnostics Korea Co. Ltd. (Seoul, Korea). The PCR amplicons were sequenced at Macrogen INC, Seoul, Korea. The determined nucleotide sequences was compared through Blast-N on GenBank database and aligned with those of other Ophiostoma species using Clustal X v1.8 program (Thompson et al., 1997) and used for primer development. The specificity of the developed PCR primers was tested by PCR against genomic DNAs from the target species and other fungal species which were known to occur on wood as sapstainers (Ophiostoma spp. and Leptographium sp.) or common mould species (Penicillium sp. and Trichoderma sp.).

For detection in wood samples, we used a method described in Kim et al. (1999b). O. floccosum spores were inoculated on a wood chip and incubated at $20^{\circ} \mathrm{C}$ 


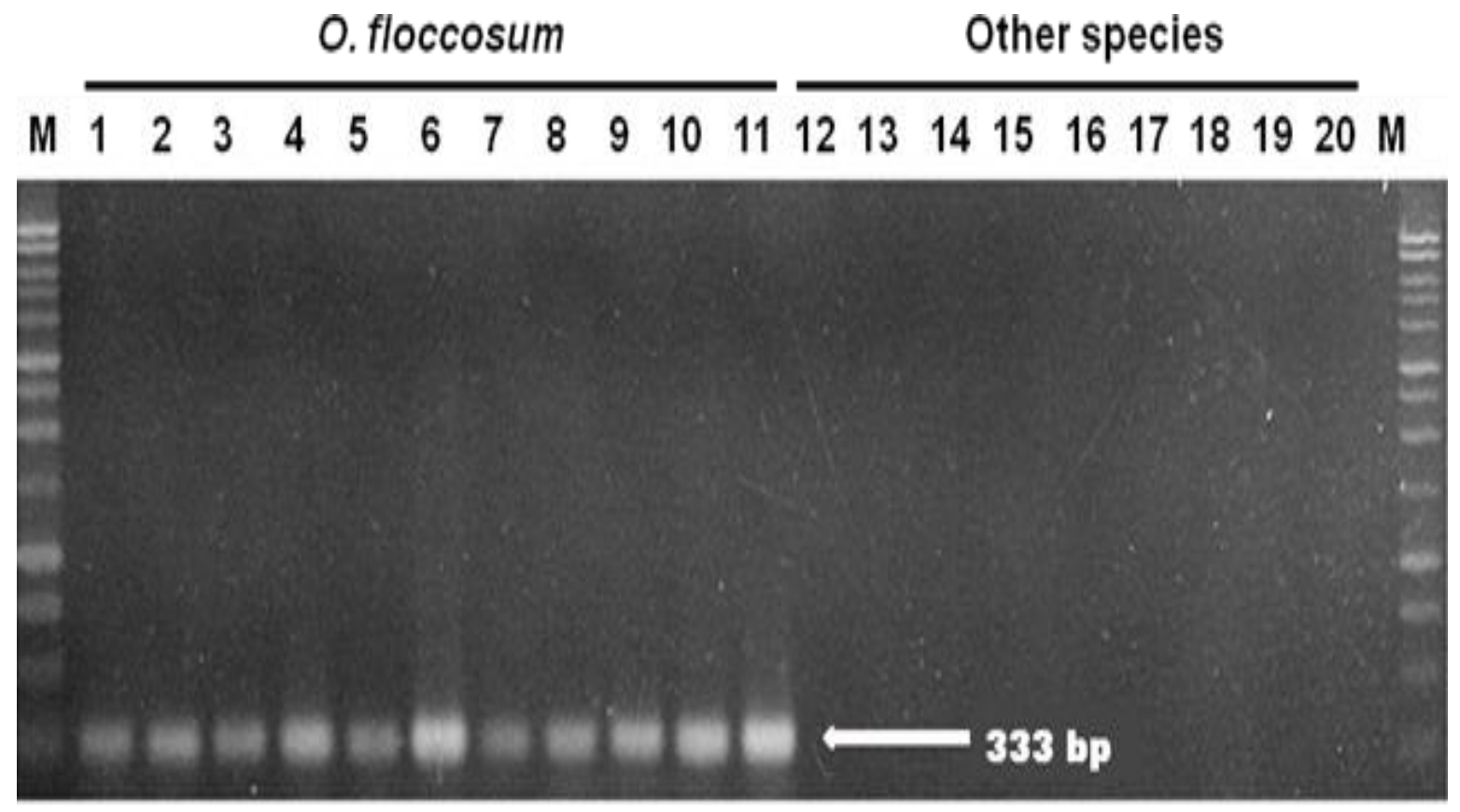

Figure 1. Gel electrophoresis of PCR products from $O$. floccosum with the primer pairs Oflo1-Oflo2. Lane M: $1 \mathrm{~kb}$ DNA ladder marker (Promega). Lanes 1-20; 1: DS1/3B-2, 2: OS-4/1-A-1, 3: KUC2072, 4: KUC2219D, 5: KUC2206, 6: KUC2420A, 7: KUC2207C, 8: KUC2225A, 9: KUC2217D, 10: KUC2215B, 11: KUC2719, 12: H2009, 13: H1042, 14: CBS118668, 15: AU123-456, 16: AU160-25, 17: AU123-151, 18: CBS118620, 19: DUCC408, 20 : DUCC409.

for 2 weeks. After incubation, the spore masses at the tip of synnemata were randomly harvested and genomic DNA was extracted by a microwave heating method (Kim et al., 1999b). With the extracted genomic DNA, the specificity of the developed primers was evaluated.

\section{RESULTS AND DISCUSSION}

Nucleotide sequence sites which are specific for 0 . floccosum were searched and selected from the Clustal_X program-aligned nucleotide sequences of the $\beta$-tubulin gene obtained from this study and those from Ophiostoma species registered in GenBank DNA database. Based on the selected sites of nucleotide sequences, two primers were designed and named as Oflo1 (forward primer 5'-CCC CTC CTC CAA ATT TAA GAG A-3') and Oflo2 (reverse primer 5'-TAG TTT CGT ATA TCA AAA CGC GTG-3'), respectively. Oflo1 targeted 20 to 41 bp position and Oflo2 targeted 329 to $352 \mathrm{bp}$ position in the $\beta$-tubulin gene sequence of $O$. floccosum 0514 (GenBank accession number JQ925340). These primers amplified only a 333 bp sized DNA band of the target gene from the genomic DNA of O. floccosum (Figure 1). Specificity of the Oflo1 to Ofl2 primers was tested by PCR against the prepared genomic DNAs from several Ophiostoma spp. and common mould species listed in Table 1. The primers did amplify the $333 \mathrm{bp}$-sized target DNA band only from eleven $O$. floccosum isolates and did not amplify other test species $(O$. piceae, $O$. quercus, $O$. ips, $O$. canum, $O$. setosum, O. minus), L. terebrantis, Trichoderma sp. and Penicillium sp. These results show that the Oflo1-Ofl2 primers are specific for $O$. floccosum. The developed Oflo1 to Ofl2 primers also successfully detected $O$. floccosum grown on wood chip (Figure 2). Since we used microwave heating for DNA extraction (Kim et al., 1999b), PCR detection of $O$. floccosum using the designed primers was feasible within $2 \mathrm{~h}$, even with DNA obtained from a single synnema. The detection was possible with $10 \mathrm{pg}$ of DNA O. floccosum 0514. The species belonging to the $O$. piceae complex has very similar morphology. Thus, morphology-based identification of $O$. floccosum is not easy and time-consuming process. Therefore, our PCR-based method will improve its diagnostics and save time.

\section{Conclusion}

Overall, PCR with designed markers in this study is rapid, specifiable and easy method for $O$. floccosum detection. The markers are expected to be applied where detection and identification of this species is needed. 


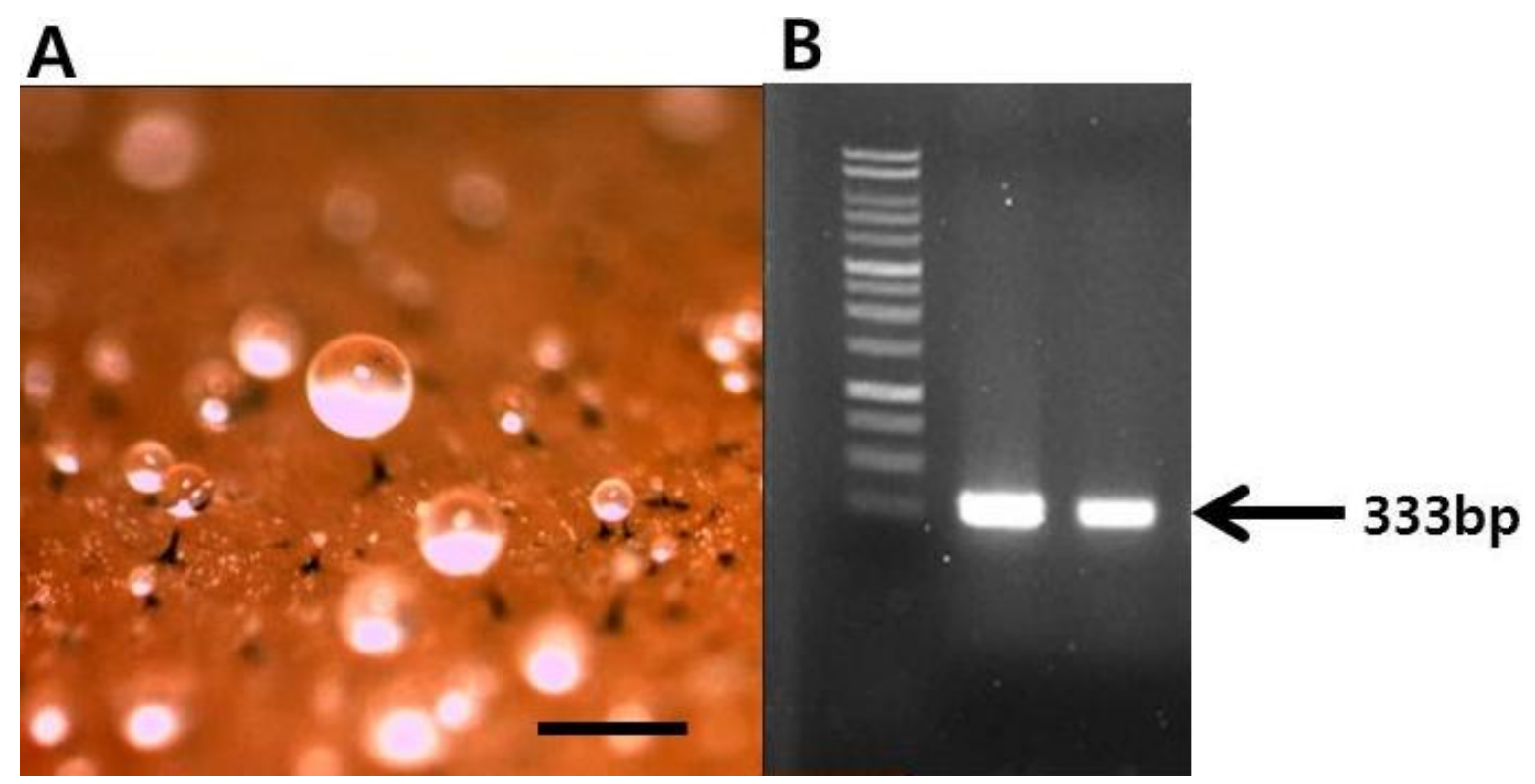

Figure 2. Evaluation of rapid detection of $O$. floccosum by PCR in artificially inoculated wood samples. A: Synnemata structure of $O$. floccosum formed on wood chip, B: Gel electrophoresis of PCR amplicons from conidial masses formed on the top of $O$. floccosum synnemata using the Oflo1-Oflo2 primers. Lane $\mathrm{M}$ : $1 \mathrm{~Kb}$ DNA ladder marker (Promega), lane 1: genomic DNA of $O$. floccosum, lane 2: conidial masses of $O$. floccosum from artificially inoculated wood chip. Scale bar $=2 \mathrm{~mm}$.

\section{ACKNOWLEDGEMENTS}

This research was supported by a grant from the Korea Institute of Planning and Evaluation for Technology of Food, Agriculture, Forestry and Fisheries (No. 30901504) and the Next Generation BioGreen 21 Program (Project No. PJ0081542011), Rural Development Administration, Republic of Korea.

\section{REFERENCES}

de Beer ZW, Wingfield BD, Wingfield MJ (2003). The Ophiostoma piceae complex in the Southern Hemisphere: a phylogenetic study. Mycol. Res. 107(4):469-476.

Harrington TC, McNew D, Steimel J, Hofstra D, Farrell R (2001). Phylogeny and taxonomy of the Ophiostoma piceae complex and the Dutch elm disease fungi. Mycologia 93(1):111-136.

Kim SH, Han A, Kronstad J, Breuil C (1999a). Diferentiation of sapstain fungi by restriction fragment length polymorphism patterns in nuclear small subunit ribosomal DNA. FEMS Microbiol. Lett. 177:151-157.
Kim SH, Uzunovic A, Breuil C (1999b). Rapid detection of Ophiostoma piceae and $O$. quercus in stained wood by PCR. Appl. Environ. Microbiol. 65(1):287-290.

O'Donnell K, Cigelnik E (1997). Two divergent intragenomic rDNA ITS2 types within a monophyletic lineage of the fungus Fusarium are nonorthologous. Mol. Phylo. Evol. 7:103-116.

Schroeder S, Kim SH, Chueng WT, Sterflinger K, Breuil C (2001). Phylogenetic relationship of Ophiostoma piliferum to other sapstain fungi based on the nuclear rRNA gene. FEMS Microbiol. Lett. 195:163-167.

Thompson JD, Gibson TJ, Plewniak F, Jeanmougin F, Higgins DG (1997). The CLUSTAL X windows interface: flexible trategies for multiple sequence alignment aided by quality analysis tools. Nucleic Acids Res. 25(24): 4876-4882.

Yun YH, Hyun MW, Suh DY, Kim SH (2009). Characterization of a sapstaining fungus, Ophiostoma floccosum, isolated from the sapwood of Pinus thunbergii in Korea. Mycobiology 37(1):5-9. 